\title{
"Modernization of the state labor market policy as a factor in overcoming the socio-economic crisis in Ukraine"
}

\begin{tabular}{|c|c|}
\hline AUTHORS & $\begin{array}{l}\text { Yurii Marshavin (D https://orcid.org/0000-0003-0144-1441 } \\
\text { R http://www.researcherid.com/rid/L-1120-2018 }\end{array}$ \\
\hline ARTICLE INFO & $\begin{array}{l}\text { Yurii Marshavin (2019). Modernization of the state labor market policy as a factor } \\
\text { in overcoming the socio-economic crisis in Ukraine. Social and labour relations: } \\
\text { theory and practice, } 9(1), 37-49 \text {. doi:10.21511/slrtp.9(1).2019.04 }\end{array}$ \\
\hline DOI & http://dx.doi.org/10.21511/sIrtp.9(1).2019.04 \\
\hline RELEASED ON & Thursday, 28 November 2019 \\
\hline RECEIVED ON & Monday, 16 September 2019 \\
\hline \multirow[t]{2}{*}{ ACCEPTED ON } & Monday, 28 October 2019 \\
\hline & $(\mathrm{cc}) \mathrm{EY}$ \\
\hline LICENSE & $\begin{array}{l}\text { This work is licensed under a Creative Commons Attribution } 4.0 \text { International } \\
\text { License }\end{array}$ \\
\hline JOURNAL & "Social and labour relations: theory and practice" \\
\hline ISSN PRINT & $2410-4752$ \\
\hline ISSN ONLINE & $2415-3389$ \\
\hline PUBLISHER & LLC "Consulting Publishing Company "Business Perspectives" \\
\hline FOUNDER & $\begin{array}{l}\text { State Higher Educational Establishment "Kyiv National Economic University } \\
\text { named after Vadym Hetman", Social and Labour Relations Institute }\end{array}$ \\
\hline
\end{tabular}

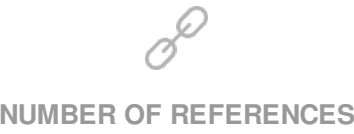

30

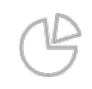

NUMBER OF FIGURES

2

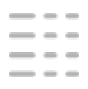

NUMBER OF TABLES

$\mathbf{0}$

(C) The author(s) 2023. This publication is an open access article. 


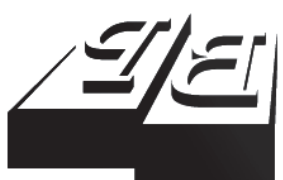

BUSINESS PERSPECTIVES

Publisher

LLC "CPC "Business Perspectives" Hryhorii Skovoroda lane, 10, Sumy, 40022, Ukraine www.businessperspectives.org

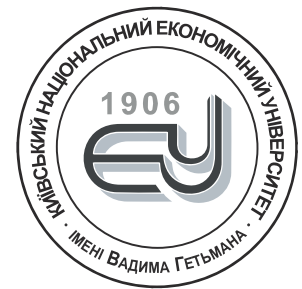

\section{HETMAN KNEU}

Founder

State Higher Educational Establishment "Kyiv National Economic University named after Vadym Hetman",

Prospect Peremogy, 54/1,

Kyiv, 03057, Ukraine

https://kneu.edu.ua/

Received on: $16^{\text {th }}$ of September, 2019 Accepted on: $28^{\text {th }}$ of October, 2019

(C) Yurii Marshavin, 2019

Yurii Marshavin, Doctor of Economics, Professor Personnel Management and Labor Economics Department, Kyiv National Economic University named after Vadym Hetman, Ukraine

\section{(c) (i)}

This is an Open Access article, distributed under the terms of the Creative Commons Attribution 4.0 International license, which permits unrestricted re-use, distribution, and reproduction in any medium, provided the original work is properly cited.

\section{MODERNIZATION OF THE STATE LABOR MARKET POLICY AS A FACTOR IN OVERCOMING THE SOCIO- ECONOMIC CRISIS IN UKRAINE}

\begin{abstract}
The relevance of the research topic is determined by the need to overcome the crisis of the Ukrainian labor market based on balancing state employment policy with other areas of social and economic policy, coordinated use of its tools aimed at forming a system of modern science-intensive jobs that meet the EU latest achievements and standards, especially in information and communication as well as digital economy.

The purpose is to analyze the causes of the crisis in the domestic labor market, identify its climate dependence on the main macroeconomic and other factors and develop new approaches to the content and toolset of modern state employment policy. The processes in the labor market, their trends and driving forces are the study object. The research used methodological provisions of Keynesian and other theories and concepts of employment, graphical and correlation analysis, content analysis, classification-analytical and statistical-analytical methods.

It has been proved that it is necessary to develop the internal market (by raising the incomes of the population) and raise the innovation-investment framework of employment based on increasing the reliability of the banking system, participation of the population in the stock market operations, develop non-governmental pension funds, credit unions, create real barriers against the money outflow, stimulate export activity of Ukrainian producers at the expense of competitive products with high added value. The use of the directions and instruments proposed in the article to modernize the state employment policy will help to overcome the labor market crisis, increase the population well-being, economic growth, and the country's entry into the trajectory of sustainable socioeconomic development.
\end{abstract}

\section{Keywords}

JEL Classification

employment policy, investment, monetary policy, household income, exports, labor market, jobs, employment, pair correlation E24, J18, J21

Ю.М. Маршавін (Україна)

\section{МОДЕРНІЗАЦІЯ ДЕРЖАВНОЇ ПОЛІТИКИ РИНКУ ПРАЦІ ЯК ФАКТОР ПОДОЛАННЯ СОЦІАЛЬНО- ЕКОНОМІЧНОÏ КРИЗИ В УКРАЇНI}

\begin{abstract}
Анотація
Актуальність теми дослідження визначається необхідністю подолання кризи ринку праці України на засадах збалансованості державної політики зайнятості 3 іншими напрямами соціально-економічної політики, скоординованого використання іiі інструментів, спрямованих на формування системи сучасних наукоємних робочих місць, що відповідають новітнім досягненням і стандартам $€ C$, перш за все в інформаційно-комунікаційної сфері та цифровій економіці.

Мета дослідження: на підставі аналізу причин кризи вітчизняного рину праці, виявити тісноту залежності його стану від основних макроекономічних та інших чинників, розробити нові підходи до змісту та інструментарію сучасної державної політики зайнятості. Об'єктом дослідження $€$ процеси на ринку праці, їх тенденції та рушійні сили. Дослідження проведено на основі методологічних положень кейнсіанської та інших теорій та концепцій зайнятості, із застосуванням графічного і кореляційного аналізу, контент-аналізу, класифікаційноаналітичного та статистично-аналітичного методів.

Доведено необхідність розвитку внутрішнього ринку (шляхом підвищення доходів населення) та піднесення інноваційно-інвестиційного базису зайнятості на підставі підвищення на-
\end{abstract}


дійності банківської системи, участі населення в операціях на фондовому ринку, розвитку недержавних пенсійних фондів, кредитних спілок, створені реальних перепон проти витікання грошей за кордон, стимулюванні експортної активності українських виробників за рахунок конкурентоспроможної продукції з високою доданою вартістю. Використання запропонованих у статті напрямів та інструментарію модернізації державної політики зайнятості сприятиме подоланню кризи ринку праці, підвищенню добробуту населення, економічному зростанню, виходу країни на траєкторію сталого соціально-економічного розвитку.

Ключові слова

Класифікація JEL політика зайнятості, інвестиції, грошово-кредитна політика, доходи населення, експорт, ринок праці, робочі місця, зайнятість населення, парна кореляція

E24, J18, J21

\section{ВСТУП}

Подолання руйнівних тенденцій та кризових явищ в сфері зайнятості, серйозних деформацій національного ринку праці, який формувався спонтанно під впливом різновекторних політичних, економічних і соціальних процесів попередніх періодів, вимагає наукового обгрунтування напрямів модернізації політики зайнятості, нових підходів до визначення інструментів їі реалізації. Стаття присвячена аналізу змісту державної політики ринку праці в Україні та розробленню методологічних та практичних засад їх модернізації.

Домінантною тенденцією в сфері зайнятості протягом останніх років стало скорочення рівня зайнятості: за підсумками 2018 р. кількість зайнятого населення (без урахування АР Крим і м. Севастополя та непідконтрольних територій у Донецькій та Луганській областях) відносно 2013 р. скоротилася на 35.6 тис чоловік, або на 6.5\%, продовжує зменшуватися середньооблікова кількість штатних працівників: у 2014 р. іх налічувалося 8.959 тис осіб, у 2016 р. - 7.868 тис, у 2017 р. лише 7.679 тис чоловік [4, с. 61]. На ситуацію не вплинув навіть процес стрімкого проникнення інформаційних технологій у всі сфери економіки і людського життя, який за словами Грішнової та Шевчук, створює новий ринок праці, що залучає мільйони нових працівників [8, с. 67]. Фактичне призупинення процесу оновлення виробничого апарату спричинило переважання у промисловості і на транспорті основних засобів 35-40-річної давнини і превалювання простої праці: майже $40 \%$ робітників зайняті на робочих місцях з переважно ручною працею $[9$, с. 7], які до того ж роками не підвищують свою кваліфікацію (його середня періодичність становить один раз на 12-15 років). Технологічна відсталість виробництв, застарілі професійні компетенції працівників унеможливлюють підвищення продуктивності праці та випуск конкурентоспроможних товарів, зростання реальної заробітної плати, за розміром якої Україна продовжує займати останні рядки в Європі. Поряд з фундаментальними прорахунками у державній соціально-економічної політиці, це призвело до катастрофічних обсягів зовнішньої трудової міграції, яка набула особливої динаміки після введення безвізового режиму перетинання кордонів з країнами ЄС. Залишається величезним молодіжне безробіття: його рівень серед молодих людей у віці до 24 -х років (включно) у два рази перевищує безробіття серед всього населення (18.9\% проти 9.5\%) [4, с. 54]. Спроби сліпого перенесення закордонного досвіду у вітчизняну сферу освіти, відсутність їі належного матеріального і фінансового забезпечення, перш за все щодо оплати праці викладачів, завдали зниження їі якості, а звідси - масовий відтік талановитої молоді у закордонні університети. Розуміння молодими людьми того факту, що їх подальші добробут i соціальний статус в Україні фактично не залежать від рівня кваліфікації та професійної майстерності, послаблює мотивацію до навчання, формує готовність до тіньової зайнятості та міграції.

Фрагментарні і безсистемні заходи влади у соціально-трудовій сфері стимулюють подальше зростання тіньового сектору економіки, який за оцінками Петрової може перевищувати третину всього зайнятого населення [22, с. 120] і характеризується приблизно таким саме обсягом виплати зарплати у “конвертах". Негативні тенденції у сфері занятості загострюються через швидке старіння населення. Скорочення частки осіб працездатного віку призвело до трикратного збільшення демографічного навантаження на зайнятих громадян: у 1990 р. на 100 працівників припадало 53, а у 2017 р. - 156 пенсіонерів. 
Все зазначене дає підстави для визнання сучасного стану ринку праці в Україні кризовим. Безперечно, на загострення цієї кризи впливає втрата значного економічного потенціалу в результаті тимчасової окупації Криму, вихід з під державного контролю окремих територій Донецької і Луганської областей, необхідність витрачати людські, матеріальні та фінансові ресурси на ведення бойових дій на Сході України. Однак, на переконання автора, основна причина кризи ринку праці полягає в іншому - у викривленому змісті державної політики зайнятості, іï стохастичному характері та невідповідності засобів, форм і методів реалізації сутності процесів і тенденцій, які відбуваються у соціально-економічній сфері України та у глобальному просторі. Сьогодні актуальним залишається твердження десятирічної давнини авторів аналітичної доповіді “Системні вади ринку праці та пріоритети його реформування”, що держава не змогла сформулювати цілісну концепцію політики на ринку праці” [24, с. 3].

Актуальність теми дослідження визначається необхідністю модернізації державної політики ринку праці, забезпечення їі збалансованості та скоординованості з іншими напрямами макроекономічної політики, системного підходу до застосування відповідних механізмів та інструментів, як передумови економічного зростання, підвищення добробуту населення, виходу України із тривалої рецесії на траєкторію сталого людського розвитку.

\section{1. ЛІТЕРАТУРНИЙ ОГЛЯА}

Проблеми розвитку ринку праці та сфери зайнятості постійно знаходяться у полі зору вітчизняних та закордонних науковців. Фундаментальні основи взаємозалежності зайнятості з макроекономічними процесами, зокрема сукупними витратами, розкрити у працях Кейнса [11]. Виходячи із кейнсіанської методології ролі держави на ринку праці, лауреат Нобелівської премії Кругман проаналізував причини вибухового зростання безробіття у США під час останньої світової фінансово-економічної кризи та запропонував для відновлення зайнятості стимулювати витрати [14]. Мають велике методологічне значення для змісту політики зайнятості публікації лауреатів Нобелівської премії 2010 р. Даймонда, Мортенсена і Писсарадеса щодо наявності так званого “ефекту розриву пошуку” - часу, протягом якого суб’єкти рина ку, в тому числі ринку праці, підбирають найкращі для себе варіанти, що зумовлює певну затримку у реакції найманих працівників та роботодавців на зміни ринкової кон'юнктури, знижує конкуренцію і сприяє їх (ринків праці) монополізації $[6,19,23]$. Важливі методологічні проблеми розвитку сфери зайнятості, зміни в характері і змісті праці, еволюції національного людського капіталу в умовах переходу до нової (цифрової, мережевої) економіки досліджуються у працях Грішнової [8], Лібанової [16], Колота та Герасименко [12]. У публікаціях Бандура [1], Петрової [22], Пищуліної [24], присвячених аналізу ринку праці та сфери зайнятості, розглянуто багато аспектів інноваційно-інвестиційного розвитку системи робочих місць, підвищення ефективності державної політики на ринку праці та її інструментарію.

Однак, незважаючи на значущість і цінність напрацювань зазначених та інших авторів, значна більшість публікацій присвячується дослідженню проблем, характерних для вітчизняної сфери зайнятості у перше десятиліття XXI ст., а причини сучасної кризи ринку праці України, методологічні засади та інструі ментарій антикризової державної політики зайнятості в умовах загострення негативних процесів у соціально-економічній сфері України, новітніх викликів і загроз залишаються недостатньо дослідженими.

\section{2. МЕТА ДОСЛІДЖЕННЯ}

На підставі аналізу причин кризового стану вітчизняного рину праці, його взаємозв'язку 3 макроекономічними та соціальними процесами розробити у контексті фундаментальних досягнень економічної науки нові методологічні підходи та інструментарій сучасної державної політики зайнятості, спрямованої на інноваційно-інвестиційне оновлення системи робочих місць як основи поширення гідної праці, динамічного соціально-економічного розвитку України є метою дослідження. 


\section{3. МЕТОДИ ДОСЛІДЖЕННЯ}

Методологічною основою роботи $є$ фундаментальні положення основних теорій і концепцій зайнятості, перш за все кейнсіанської, такі загальнонаукові методи, як аналізу та синтезу, аналітичний, порівняльний тощо, також використані методи графічного та кореляційного аналізу, контент-аналізу, класифікаційноаналітичний і статистично-аналітичний аналіз.

\section{4. РЕЗУЛЬТАТИ}

Результати аналізу свідчать, що протягом майже усього періоду ринкової трансформації в Україні реалізується відверто спрощена політика на ринку праці, яка зводиться в основному до намагання мінімізувати безробіття, особливо зареєстроване, та до реформування державної служби зайнятості, про що, зокрема, свідчать спроби зміни тї юридичного статусу (у 2012 р. в центральний орган виконавчої влади, у 2014-2015 рр. - у Національне агентство зайнятості) та перегляду структури і функцій (у 2014, 2015, 2017, 2019 pp.).

Влада бачить своє основне завдання в тому, щоб "реально боротись з безробіттям" [10] і пишається його низьким рівнем. Однак $€$ абсолютно необгрунтованим оцінювати стан такого багатогранного ринку, як ринок праці, його різноманітні сторони, прояви та властивості лише на підставі статистичних даних по безробіттю, які до того ж часто не віддзеркалюють реальну ситуацію. Непрямим, але вагомим аргумент том доведення цього твердження $є$ такий статистичний факт: незважаючи на те, що згідно з офіційними даними у нашій країні рівень безробіття є одним із нижчих в Європі та на теренах колишнього СРСР, рівень зайнятості (57.5\% за методологією МОП) на 10-12 відсоткових пунктів (далі - в.п.) нижче, ніж в Азербайджані і Латвії, на 15-16 - ніж в Казахстані та Естонії і на 20-22 в.п. - ніж в Білорусі [4, с. 519]. На думку автора, основними чинниками цього “низького" рівня безробіття є не виважена політика зайнятості, а інше. По-перше, це - результат недосконалості існуючих статистичних методів виміру зайнятості та безробіття Зокрема, викликає сумнів обгрунтованість віднесення до категорії зайнятого населення осіб, які працювали за наймом впродовж тижня хоча 6 одну годину, оскільки отримана за таку працю зарплата в умовах нашої країни не дає можливості забезпечити існування людини навіть протягом одного дня, не кажучи вже про тиждень. По-друге, поряд з недосконалістю існуючих статистичних методів виміру зайнятості, потенціал безробіття скоротився завдяки відтоку з ринку праці величезної кількості незайнятих громадян, які втратив віру у можливостях державних інституцій допомогти їм знайти гідну працю, поповнили склад економічно неактивного населення (так званих зневірених), тобто, тих, хто не має роботи і не шукає їі. Їх кількість за авторськими розрахунками складає 4-4.5 млн осіб працездатного віку. По-третє, кількість безробітних значно зменшилася у результаті зростання до небачених масштабів зовнішньої трудової міграції (за оцінками експертів вона охоплює не менше 5 млн чоловік).

Значна частка проаналізованих вище негативних процесів, тенденцій та явищ у сфері занятості $\epsilon$ результатом багаторічного нехтування державною владою, великим бізнесом потреб економічно активного населення у гідних робочих місцях. Це підтверджує, зокрема, той факт, що у стратегії сталого розвитку “Україна - 2020" із запланованих 62 реформ і програм та 25 ключових показників не міститься жодного заходу, спрямованого на реальне реформування ринку праці, та індикаторів, за допомогою яких оцінюється стан зайнятості [30].

Ігноруючи норми вітчизняного законодавства, які чітко вимагають від державних органів реалізації політики у сфері зайнятості населення шляхом проведення податкової, кредитно-грошової, інвестиційної, бюджетної, соціальної, інноваційної та зовнішньоекономічної політики [29, с. 16], влада розглядала ринок праці і складники соціально-економічної політики окремо один від одного, перетворюючи їх у самоціль. Незважаючи на постійне загострення соціально-економічної кризи, центральні та місцеві органи державної виконавчої влади та органи місцевого самоврядування намагалися вирішити фундаментальні і надзвичайно складні проблеми у сфері зайнятості якимись окремими фрагментарними заходами, до того ж нескоординованими не лише з макроекономічними процесами, а й між собою. В урядових колах 
багато років панувало переконання, що оздоровлення сфери зайнятості можна досягти прийняттям декількох “гарних" указів і постанов та підвищенням вимогливості до органів державної виконавчої влади обласного та районного рівнів. Але, як свідчать результати аналізу, реальний ефект подібних заходів зазвичай наближається до нуля, перш за все через те, що більшість 3 них не відповідають економічним законам і закономірностям, не враховують причинно-наслідкові зв’язки, які об'єктивно існують в економіці. Зусилля спрямовувалися на подолання проявів хвороби (тривалість безробіття, іï

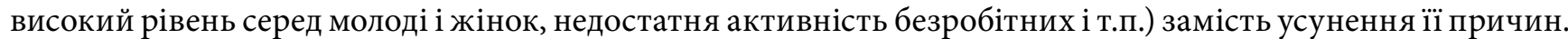
Показники, яких намагалися досягти, зазвичай бралися “зі стелі", без будь-яких розрахунків, зокрема не враховувалися доходи населення, тенденції у грошово-кредитної, фіскально-бюджетної, інвестиційної, зовнішньоекономічної сферах. Так, в останній Програмі сприяння зайнятості населення (на період 2012-2017 рр.) із 60 позицій розділу “Шляхи розв’язання проблеми” немає жодної, де 6 передбачалися конкретні макроекономічні заходи і фінансові ресурси, необхідні для “розв’язання проблеми” [28]. Навіть пункт “Залучення інвестицій з метою забезпечення розвитку пріоритетних видів економічної діяльності та інфраструктури” не містив жодної цифри. У той же час у Програмі без будь-якого обгрунтування зазначалися показники, яких планувалося досягти у сфері зайнятості, тому не дивно, що вони залишилися лише на папері. Зокрема рівень зайнятості населення віком 15-70 років за підсумками 2017 р. склав 55.4\%, що не лише на 7.9 в.п. менше ніж передбачалося, а й на 4.2 в.п. нижче рівня, який мав місце на момент прийняття програми у 2012 р. [4, с. 49, 51, 62].

Однак найбільш яскравим прикладом відсутності позитивних результатів від програм у сфері зайнятості, які не узгоджувалися і не забезпечувалися засобами макроекономічної політики, став прийнятий в липні 2005 р. План дій Президента України Ющенко “Десять кроків назустріч людям”, однією з основних цілей якого визначалося створення за п’ять років п’яти мільйонів нових робочих місць - щорічно не менш, ніж по 1 млн [26]. Природно, що через застосування типового для нашої влади підходу, про який ішлося вище, виконання цього, так званого плану дій, не пішло далі кабінетів урядовців. У підсумку, незважаючи на звіти, в яких стверджувалося повне виконання Плану, кількість зайнятих в Україні за період 2005-2009 рр. не лише не збільшилася на 5 млн чоловік, а скоротилася майже на 0.5 млн чоловік (3 20.680 до 20.192 тис), а чисельність найманих працівників зменшилася більш, ніж на один млн (з 14.005 до 12.949 тис) [4, с. 49, 51, 61, 62].

Підсумовуючи викладене, наголосимо на авторській позиції, яка полягає у тому, що розв'язання чисельних соціально-економічних проблем неможливо без модернізаціїдержавної політики зайнятості на принципово нових теоретико-методологічних засадах, що вимагає перенесення вістря макроекономічної політики на розвиток сфери зайнятості. У цьому контексті доцільно зауважити, що законом США про Федеральну резервну систему (ФРС) визначено основним завданням Ради директорів ФРС і Федерального комітету з операцій на відкритому ринку забезпечення максимальної зайнятості (виділено автором), цінової стабільності та помірних довгострокових відсоткових ставок [25]. Тобто, американські урядовці ставлять у центр макроекономічної політики саме досягнення високого рівня зайнятості.

Сукупний попит як фундамент формування зайнятості населення. В основі створення продуктивної системи робочих місць відповідно до основних положень сучасної кейнсіанської теорії зайнятості лежить сукупний попит. Ще у 1930-х рр. Кейнс доводив, що зайнятість $€$ функцією ефективного попиту - “такого значення сукупного попиту, котре стає фактично реалізованим" [11, с. 33, 57]. Тобто, у ринкових умовах рівень зайнятості багато у чому визначається обсягом сукупного попиту, який включає чисті недержавні інвестиції, особисті споживчі витрати, чистий експорт, а також державні закупівлі національного продукту [17, с. 176-180]. У кейнсіанської теорії визнано, що за даної величини показника, який їі автор назвав схильністю суспільства до споживання, рівноважний рівень зайнятості залежить від величини поточних інвестицій. Це положення не заперечується навіть найвидатнішими опонентами Кейнса. У сьогоднішній вітчизняній економічній науці також вважається загальновизнаним, що створення $\mathrm{i}$ модернізація робочих місць відбувається на основі капітальних інвестицій. Водночас створення фізичних робочих місць $€$ необхідною, але не достатньою умовою позитивних змін у сфері зайнятості. Товари $\mathrm{i}$ послуги, що вироблятимуться на нових робочих місцях, мають знайти свого споживача - користуватися реальним попитом. 3 цього приводу, лауреат Нобелевської премії 2008 р. Кругман, аналізуючи шляхи 
виходу США із останньої фінансово-економічної кризи, стверджував: “Якщо правильно змінити курс від політики жорсткої економії до заохочення споживання, ми можемо відновитися досить швидко”. Далі, критикуючи економічний курс американських політиків “на затягування пасків", зазначав: “Серед тих, кого ми звемо “великі дядьки”, не враховується головний постулат Кейнса, який казав, що економити треба під час буму, а не спаду” [14, с. 9-10].

Стосовно сучасної економіки України зазначений вплив підтверджується результатами проведеного автором цієї статті графічного аналізу залежності рівня зайнятості населення від обсягу капітальних інвестицій та розміру доходів населення, як основи споживчих витрат, а також від експорту (Рисунки 1 i 2). 3 метою виключення впливу на результати аналізу інфляції обсяги капітальних інвестицій та доходи населення обраховані у цінах 2000 p.

Як видно на графіку, характер кривих, що характеризують динаміку рівня зайнятості населення, капітальних інвестицій та доходів населення, $є$ досить близьким. Наявність окремих випадків асинхронності та різновекторності змін зазначених показників пояснюються тім, що рівень зайнятості визначається не лише змінами цих макроекономічних складників, а й є рівнодіючою взаємодії цих та багатьох інших показників. До того ж на сферу зайнятості крім економічних впливають інституційні чинники, політичні, демографічні, соціальні та інші процеси. Звідси - результуюча їх комбінація не завжди співпадає з обсягом сукупних витрат або одним з його складників. Зокрема, у наших сучасних умовах зазначені розбіжності пов’язані: з військовими діями на Сході України, які викликали переміщення великих мас населення (приблизно 1.5 млн осіб), більшість якого не змогла одразу працевлаштуватися на нових місцях проживання; віднесенням у статистиці. частини членів особистих селянських господарств, які вважалися незайнятими, до зайнятого населення [27, ст. 8]; підвищенням пенсійного віку для жінок; поширенням корупції у владних структурах і правоохоронних органах, що негативно впливає на ведення бізнесу, а звідси - на створення і збереження робочих місць.

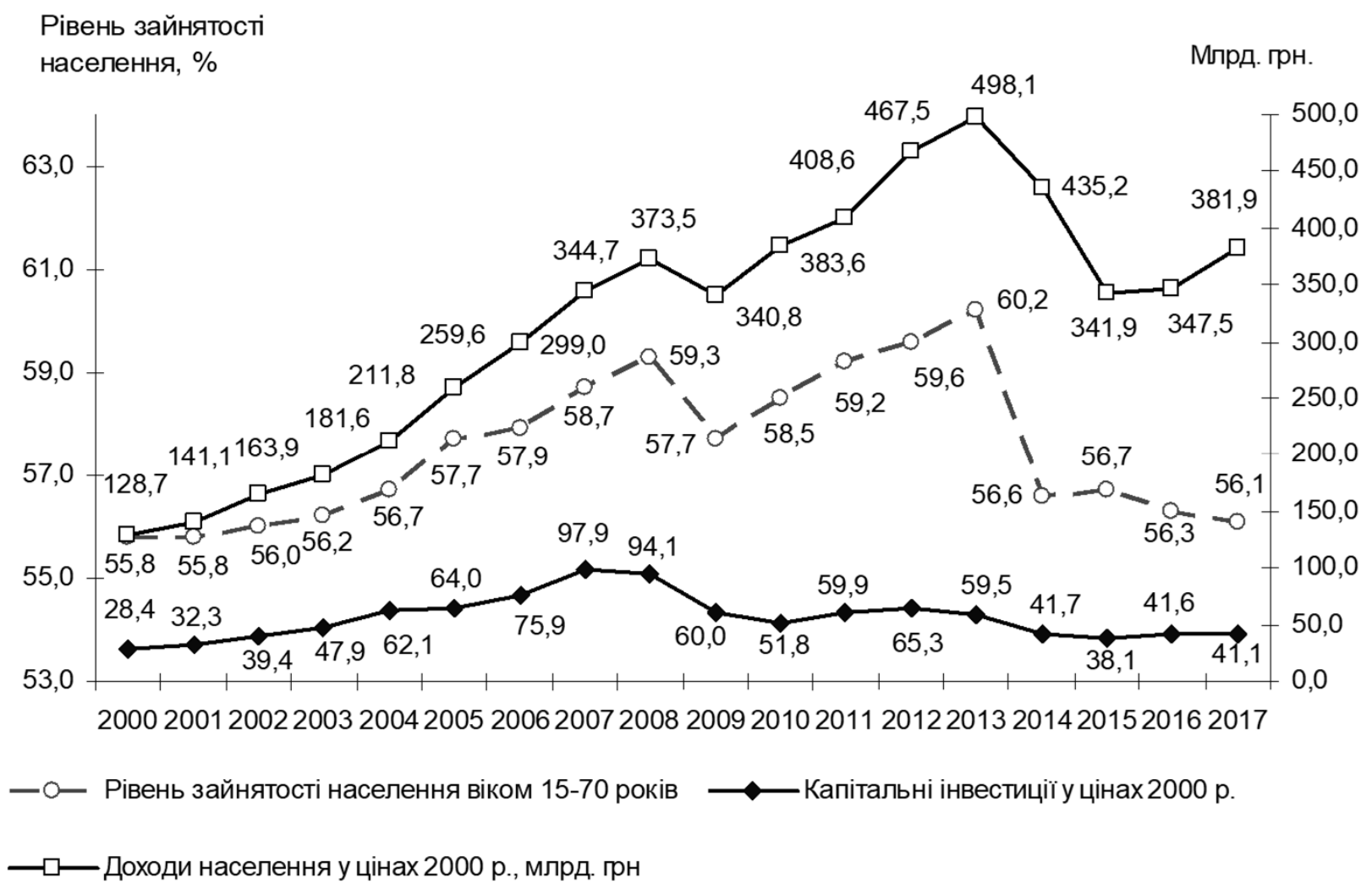

Рисунок 1. Динаміка рівня зайнятості населення віком 15-70 років, обсягів капітальних інвестицій та доходів населення (у цінах 2000 р.) 
Для перевірки тісноти зв’язку між рівнем зайнятості та кожним із зазначених показників розрахуємо коефіцієнт парної кореляції - добутку моментів Пірсона (віддзеркалює ступінь лінійної залежності між двома множинами будь-яких даних), використовуючи відповідні статистичні показники за 18-річний період (2000-2017рр.). Розрахунки проведемо з використанням пакету прикладних програм середовища Windows (Microsoft Office Excel 2003) за формулою [13, с. 51]:

$$
r=\frac{n \sum_{i=1}^{n}\left(x_{i}-\bar{x}\right)\left(y_{i}-\bar{y}\right)}{\sqrt{\sum_{i=1}^{n}\left(x_{i}-\bar{x}\right)^{2}} \sqrt{\sum_{i=1}^{n}\left(y_{i}-\bar{y}\right)^{2}}},
$$

де $x_{i} y_{i}$ - значення відповідно рівня зайнятості населення віком 15-70 років та обсягів капітальних інвестицій (у цінах 2000 р.) у кожен рік періоду 2000-2017 pp., $\bar{x}, \bar{y}$ - середні арифметичні значення рівня зайнятості населення віком 15-70 років та обсягів капітальних інвестицій за зазначений період (18 років), $n$ - кількість років.

Для визначення ступеня залежності рівня зайнятості від доходів населення у зазначеної формулі символи $y_{i}$ та $\bar{y}$ означатимуть вже доходи населення у відповідні роки та їх середньоарифметичні значення за 18 років.

У результати розрахунків отримуємо значення коефіцієнтів парної кореляції між рівнем зайнятості населення та: обсягом капітальних інвестицій - 0.64; доходами населення - 0.98, що підтверджує наявність досить високої взаємозалежності між рівнем зайнятості та зазначеними показниками.

Капітальні інвестиції як важливий засіб збереження існуючих та створення нових продуктивних робочих місиь. Як зазначалося вище, для формування продуктивної зайнятості першочергове значення має процес інвестування.

Низький відносно іншого показника коефіцієнт кореляції між рівнем зайнятості та обсягами капітальних інвестицій пояснюється проявом хвильового ефекту впливу інвестицій на сферу зайнятості. За авторською концепцією, за рівності і незмінності інших умов, інвестиції відбиваються на параметрах зайнятості своєрідними хвилями, кожна із яких має свою природу, силу і тривалість впливу [18]. Перша (коротка) хвиля відбивається на сфері зайнятості безпосередньо і майже миттєво та пов'язана 3 надходженням інвестиційних коштів у галузі економіки, що виробляють засоби виробництва, створюючи передумови для збільшення кількісного складу фізичних робочих місць в будівництві, на підприємствах, що виробляють машини, механізми, обладнання. Друга (довга) хвиля від капітальних інвестицій віддзеркалюється на обсязі зайнятості за більш тривалий час - зазвичай 2-3 роки. Вона проявляється у створенні нових та модернізації функціонуючих робочих місць на підприємствах, що виробляють товари та надають послуги з використанням обладнання, машин і механізмів, що створюються в результаті дії першої інвестиційної хвилі. Саме через хвильовий характер впливу капітальних інвестицій на зайнятість періоди між часом вкладання коштів до зміни кількісних та якісних параметрів зайнятості значно відрізняються, у залежності від того, наслідками якої хвили вони є. До того ж ці хвилі можуть накладатися одна на одну. Все це ускладнює ідентифікацію зміни обсягу зайнятості від здійснення конкретних інвестицій, що може зменшувати показник тісноти кореляційного зв’язку.

Однак навіть з врахуванням зробленого зауваження, результати проведених графічного та кореляційного аналізів дають підстави для твердження: рівень зайнятості населення досить чуйно реагує на процеси інвестування, що вимагає пошуку джерел збільшення обсягу капітальних інвестицій у нашій країні.

Оскільки за даними Національного інституту стратегічних досліджень створення одного робочого місця в Україні коштує у середньому 15.4 тис євро [21], для забезпечення ними лише безробітних (1.21.5 млн осіб) потрібні капітальні інвестиції у розмірі 550-670 млрд грн, що у 1.5-1.7 рази перевищує їх сьогоднішній річний обсяг. 
На переконання автора, надія, яку довгий час педалюють вітчизняні урядовці та ЗМІ, щодо можливості активізації інвестиційної діяльності за рахунок іноземних капіталовкладень, не має серйозного обгрунтування: їх частка у загальному обсягу інвестицій коливається навколо 2.5-3.0\%, а у 2017 р. склала всього $1.4 \%$ [4, с. 359]. Аргументацію такої незначної частини закордонних інвестицій посиланням на військові дії на Сході України можна сприйняти лише частково. Адже добре відомо, що іноземні інвестори “йдуть слідом" за вітчизняними, які, на жаль, спрямовують кошти за кордон. Так, прямі інвестиції з України в економіки інших країн (96.4\% з них - у країни ЄС) перевищили на кінець 2017 p. 6.6 млрд доларів США, що у 39 разів більше, ніж у 2000 p. [4, с. 405]). Але фактично втрати вітчизняних фінансових ресурсів $є$ набагато більшими. Аналіз інформації розташованих у США міжнародних неурядових організацій Global Financial Integrity (GFI) [3] та Tax Justice Network [7], які відслідковують рух фінансових потоків, дає підстави вважати, що за роки незалежності щорічний витік коштів з України складав 10-15 млрд доларів США. Вірогідно, ці кошти повернути в Україну не вдасться, але застосування надійних перепон проти подальшого витікання грошей за кордон створило 6 передумови для зростання інвестиційного базису зайнятості.

Не виконують інвестиційної функції фондовий ринок та вітчизняна банківська система. Через свою нерозвиненість, фондовий ринок України не перерозподіляє вільні кошти домогосподарств у сферу бізнесу як фінансовий ресурс інвестицій, і ця функція частково перекладена на банківську систему. Але між владою і банківською системою склалося взаємовигідне статус-кво, за якого їх інтереси досягалися, але при цьому потреба в інвестиціях у робочі місця ігнорувалася. Насправді: з одного боку, забезпечується можливість отримання надійного прибутку комерційними банками за рахунок розміщення грошей на депозитних рахунках Національного банку та здійснення операцій з надприбутковими облігаціями внутрішньої державної позики (далі - ОВДП). 3 іншого боку, держава отримує надійне джерело заповнення “дірок” у державному бюджеті. Так, на 01 липня 2019 р. комерційні банки, у тому числі чотири державні, володіли державними цінними паперами на 383 млрд грн, а ще 48 млрд грн розмістили на депозитних рахунках НБУ [27]. Якщо 6 ці кошти (431 млрд грн) були використані комерційними банками для кредитування бізнесу, це могло 6 збільшити обсяг капітальних інвестицій, достатній для створення 900 тис нових сучасних робочих місць.

Саме через орієнтацію на самозамкненість банківської системи і надмірно високі відсоткові ставки за кредитами, позиковий капітал у складі інвестицій становить невиправдано низьку частку, яка до того ж щорічно зменшується: у 2014 р. вона складала 9.9\%, у 2015 р. - 7.6\%, у 2016 р. - 7.5\%, у 2017 р. - 6.6\% [4, c. 359]. Звідси випливає, що для подальшого зростання обсягу капітальних інвестицій, зокрема, потрібне удосконалення державної грошово-кредитної політики, іiі спрямовання на зниження відсоткових кредитних ставок, які значною мірою визначаються співвідношенням попиту і пропозиції на грошовому ринку. У свою чергу, для збільшення пропозиції грошей комерційними банками недостатньо використовується єдиний реальний і найбільш потужний ресурс - гроші населення, яке зберігало у 2018 р. поза банківською системою 400 млрд грн і 86 млрд доларів США [20], що сумарно складало майже 2.5 трлн грн. Залучення у банківську систему цього фінансового ресурсу могло 6 примітно вплинути на зменшення відсоткових ставок по кредитам і значне збільшення обсягу інвестицій у створення та модернізацію робочих місць. Однак банківські кризи середини 1990-х рр. і 2008-2009 рр. значно підірвали довіру населення до вітчизняних комерційних банків. Особливо сильний удар по авторитету банківської системи спричинила політика їі так званого оздоровлення у 2014-2017рp., у результаті якої ліквідовано понад 90 комерційних банків і багато тисяч громадян повністю або частково втратили свої заощадження. У результаті вітчизняній банківській системі не довіряло не лише населення, але навіть високопосадовці, які зберігали великі суми грошей готівкою поза банків (близько 72\% задекларованих коштів), про що свідчить зміст їхніх декларацій у 2018 р. про майно, доходи, витрати і зобов'язання фінансового характеру [2].

Для відродження довіри до банківської системи влада, НБУ мають здійснити реальні заходи, спрямованіна забезпечення надійності банківської системи, посилення її привабливості. Зокрема, доцільно розробити механізм, спрямований на гарантоване повернення фізичним та юридичним особам депозитних вкладів у повному обсязі у тій самій валюті, у якій вони робилися. Для цього можна, зокрема, запровадити систему страхування вкладів населення комерційними банками. 
На думку автора, у забезпеченні коштами інвестиційного процесу також слід активніше використовувати такий досить потужний засіб залучення та концентрації інвестицій на інноваційних напрямах, як фондовий ринок. Необхідно, зокрема, створити умови для безпроблемного придбання фізичними особами облігацій внутрішньої державної позики через комерційні банки. Для цього доцільно подолати штучні перепони придбання ОВДП населенням, при цьому зменшити невиправдано великі комісійні збори банків при купівлі та продажу цих цінних паперів та знизити вартість мінімального пакету, яка у більшості банків сьогодні сягає сотні тисяч або навіть мільйони гривень. Також потребує розвитку такий потенційно потужний інвестиційний ресурс, як приватні і корпоративні пенсійні фонди, кредитні спілки.

У контексті створення сучасних робочих місць в умовах обмеженого інвестування принципово важливим $€$ не лише нові підходи до визначення і використання джерел інвестицій, але i зміна їх структури - об’єктів інвестування. Державна політика зайнятості має стимулювати перенесення акценту з інвестування підприємств торгівлі, розваг та будівництва офісів на створення виробничих потужностей. Як справедливо зауважує з цього приводу Бандур, здійснюючи певні інвестиції, суб’єкти економічних відносин, незалежно від форм власності, мають формувати більш якісну структуру робочих місць, підпорядковану не лише і не стільки потребам сьогодення, скільки новітнім вимогам і стандартам Європейського Союзу [1, с. 11]. Аналізуючи інвестиційний вплив на сферу зайнятості, також слід погодитися з думкою академіка Лібанової щодо необхідності спрямувати державну політику зайнятості не лише на подолання негативних тенденцій у цій сфері, а й на сприяння розвитку зайнятості в інноваційному напрямі, для чого доцільно виокремити одним із пріоритетів цієї політики створення сучасних наукоємних робочих місць [16, с. 257]. Отже, необхідне державне стимулювання процесу вкладання коштів у перспективні робочі місця, які відповідають вимогам гідної праці, за допомогою яких вироблятиметься інноваційна і конкурентоспроможна продукція для внутрішнього і зовнішнього ринків. Важливо, щоб державна політика зайнятості була спрямована на формування системи робочих місць майбутнього з врахуванням тенденцій не лише у техніко-технологічної, а і в соціально-трудовій сфері. Адже, за справедливим твердженням Колота та Герасименко, інформаційно-комунікаційні,цифрові та інші проривні технології “Індустрії 4.0” обумовлюють утвердження як нового формату глобалізації та глобального суспільного поділу праці, так і нової платформи соціально-трудового розвитку [12, с. 98].

Доходи населення як вирішальний чинник зайнятості. Створення фізичних робочих місць у результаті інвестування $€$ необхідною, але не достатньою умовою позитивних змін у сфері зайнятості. Підприємства прийматимуть на роботу працівників за умови, що товари і послуги, що вироблятимуться, знайдуть свого споживача - користуватимуться реальним попитом, основою якого є доходи населення. Результати проведених вище графічного та кореляційного аналізів показують найбільшузалежність рівня зайнятості саме від розмірів доходів населення (коефіцієнт кореляції склав 0.98). Проте сьогодні для населення України характерні надзвичайно низькі доходи, що відповідно знижує частку споживчих витрат у сукупному попиті, а звідси - негативно впливає на рівень зайнятості. І хоча розміри номінальних зарплат і пенсій - основних джерел доходів населення, постійно зростають, але через високі темпи інфляції це не спричиняє адекватного збільшення фізичного обсягу споживання вітчизняної продукції. На зниження купівельної спроможності населення також впливає інтенсивне вимивання коштів із домогосподарств через підвищення цін на комунальні послуги та енергоресурси - за 7 років витрати на ці потреби вирослі майже у два рази: у 2010 р. частка оплати житла, комунальних продуктів і послуг, води, газу та електроенергії у сукупних витратах домогосподарств складала 16.8\%, а у 2017 р. - 32.4\% [4, с. 91]. Можна навести багато аргументів щодо величезного заниження розміру реальної заробітної плати на користь прибутків і надприбутків великого капіталу. Але підкреслимо лише такий факт: якщо у 1990 р. питома вага зарплати у складі ВВП становила 53.1\%, у 2012 р. - 50.5\%, у 2017 р. - 43.3\%, у 2018 р. - 41.5\% [4, с. 209]. Низькою залишається частка зарплати у собівартості продукції - біля 13\%, що за розрахунками Кулікова, у два рази менше, ніж в ЄС і майже у три - ніж у Німеччині та Франції [15].

Розміри споживання багато у чому визначаються обсягом пенсійних виплат. Державна соціальноекономічна політика щодо пенсійного забезпечення, яка зараз побудована на встановленні захмарних пенсій окремим категоріям можновладців та зрівнялівці у розмірах пенсій особам з багаторічним 
трудовим стажем і тими, хто працював нетривалий час, або не працював взагалі у зареєстрованому секторі економіки, має поступитись місцем політиці, що прямо і однозначно стимулюватиме людей до наполегливої, тривалої і чесної праці у зареєстрованому секторі економіки. Людину, починаючи 3 шкільних років, треба орієнтувати не на очікування різноманітних подачок від держави (дотацій, компенсацій і т.п.), а на збільшення сум та тривалості сплати внесків у солідарну та накопичувальну частини пенсійного фонду. До того ж треба спростити систему нарахування пенсій, щоб працівник мав змогу самостійно розрахувати розмір майбутньої пенсії в залежності від розміру зарплати і тривалості періоду праці у зареєстрованому секторі економіки. Лише розуміння того, що кожен день такої праці і кожна гривня внесків у пенсійний фонд обов'язково у майбутньому позначиться на розмірі пенсії, може економічно примусити особу продуктивно працювати в офіційній економіці.

Вплив на сферу зайнятості експортної активності бізнесу. На стан сфери зайнятості також здійснює значний негативний вплив скорочення українського експорту. Відповідно до хрестоматійних положень економічної науки експорт має доповнювати внутрішній попит на вітчизняні товари й послуги, стимулюючи розвиток виробництва, а звідси - й зайнятості. Наочно це положення стосовно України підтверджується відповідними кривими на Рисунку 2.

Як показує характер кривих, зображених на Рисунку 2, та результати проведеного автором розрахунку коефіцієнта парної кореляції (за Пірсоном) показники, що досліджуються, знаходяться у дуже значної взаємозалежності між рівнем зайнятості населення та експортом (0.93) - збільшення розміру експорту спричиняє зростання зайнятості. Отже, зменшення рівня зайнятості останнім часом багато в чому визначено скороченням українського експорту - за 5 років на 35\%. Водночас у контексті зайнятості населення має значення також структура українського експорту, в якому переважає первинна і проміжна продукція. Зокрема у 2018 р. частка продуктів рослинного походження, мінеральних продуктів і недорогоцінних металів склала 53.7\% до загального обсягу (у 2015 р. - 39.3\%), а машин, обладнання, механізмів - 9.8\% (у 2015 р. - 16.9\%) [4, с. 25, 395; 20]. У результаті, посилюються диспропорції в структурі зайнятості населення, зокрема відбувається скорочення частки зайнятих у промисловості, перш за все у машино-та приладобудуванні, інших високотехнологічних галузях.

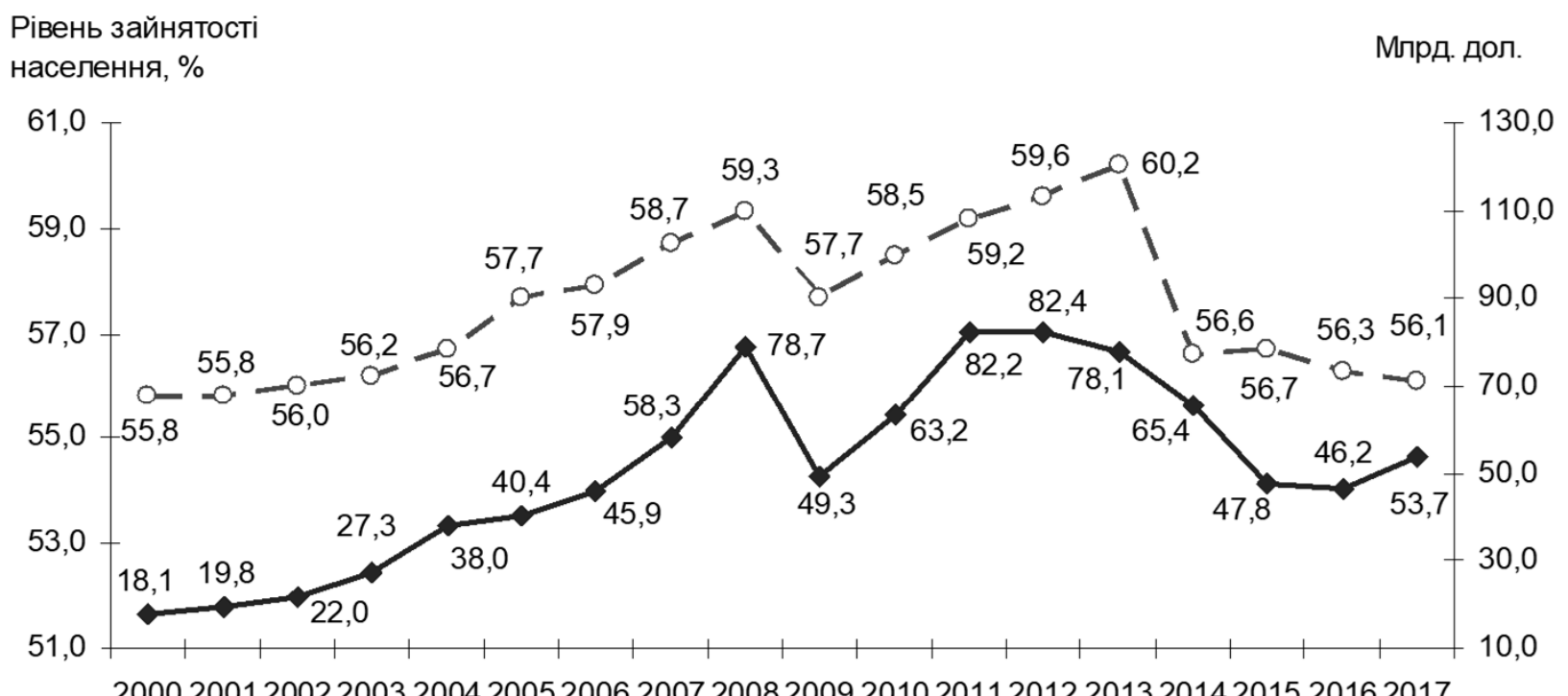

200020012002200320042005200620072008200920102011201220132014201520162017

- - Рівень зайнятості населення віком $15-70$ років

$\longrightarrow$ Експорт товарів і послуг

Рисунок 2. Динаміка рівня зайнятості населення віком 15-7о років та обсягу експорту товарів і послуг 
Для розвитку сфери зайнятості важливо змінити зовнішньоекономічну модель, зокрема місце України у міжнародному поділі праці, яка останнім часом все більше виконує роль аграрного придатку західних країн. Нова парадигма зовнішньоекономічної діяльності має базуватися не на сприятливій кон'юнктурі аграрної продукції та сировини на світових ринках і привабливому для експортерів обмінному курсі валют, а на переорієнтації виробництва на наукоємну інноваційну продукцію високого ступеня переробки, що має забезпечити іiі високу конкурентоспроможність. Також необхідно розвивати інфраструктуру експорту, зокрема, сформувати розгалужену систему збуту товарів і послуг за кордоном шляхом створення мережі торгових представництв, комерційних агентств, оптових складів, виставкових центрів, налагодити консалтингову, маркетингову і рекламну підтримки наших товарів і послуг за кордоном.

\section{ВИСНОВКИ}

Державна політика зайнятості в Україні майже вісь період ринкової трансформації має спрощений характер як за змістом, так й за механізмами та інструментами реалізації. Влада намагається вирішити фундаментальні і надзвичайно складні проблеми у сфері зайнятості окремими фрагментарними заходами, нескоординованими не лише з макроекономічними процесами, а й між собою. Природним $\epsilon$ результат такої соціально-економічної політики взагалі і політики зайнятості зокрема: падіння доходів населення, зростання кількості співвітчизників, які шукають кращої долі на чужині, перетікання працівників у незареєстрований сектор економіки, поширення утриманських настроїв в суспільстві, посилення податкового навантаження на офіційно зайнятих громадян.

Модернізація державної політики ринку праці має будуватися на принципово нових теоретикометодологічних засадах, перенесенні вістря макроекономічної політики на розвиток сфери зайнятості, посиленні координації інвестиційної, грошово-кредитної, податкової політики, зовнішньоекономічної діяльності, політики доходів з потребами людей у продуктивних робочих місцях та гідній оплаті праці.

Із результатів дослідження випливає, що головним для формування зайнятості на інноваційній основі $€$ розвиток внутрішнього ринку, фундаментальною основою якого мають стати високі реальні доходи населення, перш за все заробітна плата і пенсії, та значні за розміром та раціональні за сферами прикладання інвестиції у розвиток основного капіталу, здійснення техніко-технологічних нововведень. Державна політика має стимулювати суб'єктів інвестування на формування якісної структури робочих місць, підпорядкованої не стільки потребам сьогодення, скільки новітнім вимогам і стандартам ЄС, створення сучасних наукоємних робочих місць, перш за все у сфері інформаційно-комунікаційної, цифрової та інших проривних технологіях “Індустрії 4.0”. Для цього слід ефективніше використовувати внутрішні ресурси, перш за все кошти населення, розвивати фондовий ринок, зокрема створити умови для безпроблемного придбання фізичними особами та малим бізнесом облігацій внутрішньої державної позики, інших цінних паперів. Авторська позиція полягає, зокрема, у гострій необхідності створення механізму, який забезпечить надійність банківської системи та посилення ролі НБУ, правоохоронних органів у профілактиці та попередженні фактів витікання значних сум грошей в офшори та закордонні банки. Для розширення обсягу та оптимізації структури зайнятості необхідно стимулювати експортну активність українських підприємств, яка має базуватися на виробництві конкурентоспроможної продукції з високою доданою вартістю та створенні розвинутої інфраструктури експорту, зокрема, розгалуженої системі збуту товарів і послуг за кордоном, консалтингової, маркетингової і рекламної підтримки вітчизняних товарів і послуг в інших країнах.

Практичне застосування результатів проведеного дослідження у зміст державної політики ринку праці, запропоновані інструменти їі модернізації дадуть змогу оздоровити сферу зайнятості, активізувати процес створення нових і розширення існуючих продуктивних та інноваційних робочих місць, залучення населення у сферу зареєстрованої зайнятості з гідною оплатою праці. Подальші дослідження політики ринку праці пропонується поширити на визначення кількісних показників залежності розвитку сфери зайнятості від динаміки складників сукупного попиту, розробку відповідної економіко-математичної моделі. 


\section{СПИСОК ЛІТЕРАТУРИ}

1. Bandur, S. I., \& Kovenska, O. A. (2015). Theoretical and Methodological Imperatives of State Regulation of the Labour Market in the Context of Economic Reform in Ukraine. Rynok pratsi ta zainiatist naselennia - Labor Market and Employment, 2, 9-13. (In Ukrainian). Retrieved from http://nbuv.gov.ua/UJRN/rpzn_2015_2_3

2. Bihus.info (2017). Dovira deklarantiv do bankivskoi systemy [Declarants' confidence in the banking system]. (In Ukrainian). Retrieved from https://bihus.info/bilse-70-zadeklarovanih-kostiv-cinovniki-trimaut-v-gotivci

3. Clough, Ch. (2015). New Study: Illicit Financial Flows Hit US\$1.1 Trillion in 2013. Retrieved from https://bitly.su/9vpsp

4. Derzhavna Sluzhba Statystyky Ukrainy (2018). Statystychnyi shchorichnyk Ukrainy za 2017 rik [Statistical Yearbook 2017] (540 p.). Kyiv: Derzhavna sluzhba statystyky Ukrainy. (In Ukrainian). Retrieved from https://ukrstat.org/uk/druk/publicat/kat_u/2018/zb/11/zb_ seu2017_u.pdf

5. Derzhavna sluzhba statystyky Ukrainy (2018). Tovarna struktura zovnishnoi torhivli u 2018 rotsi [Commodity structure of foreign trade in 2018]. (In Ukrainian). Retrieved from http://www.ukrstat.gov.ua/operativ/operativ2018/zd/tsztt/tsztt_u/tsztt1218_u.htm

6. Diamond, P. A. (1998). Optimal Income Taxation: An Example with a U-Shaped Pattern of Optimal Marginal Tax Rates. American Economic Review, 88(1), 83-95. Retrieved from https://www.jstor.org/stable/116819?seq=1\#page_scan_tab_contents

7. Finance.ua (2012). Za roky nezalezhnosti z Ukrainy v ofshory vyvely 170 miliardiv dolariv [During the years of independence from Ukraine, \$ 170 billion was brought to the offshore]. (In Ukrainian). Retrieved from https://bitly.su/8307pgtd

8. Hrishnova, O. A., \& Shevchuk, V. A. (2018). World and Ukrainian Labor Market in the Sphere of Web Technologies: Comparative Evaluation of Professional Attraction. Sotsialno-trudovi vidnosyny: teoriia ta praktyka, 1, 59-68. (In Ukrainian). Retrieved from http:// nbuv.gov.ua/UJRN/stvttp_2018_1_6

9. International Labour Organization (2016). Prohrama hidnoi pratsi MOP dlia Ukrainy na 2016-2019 roky [ILO decent work agenda for Ukraine, 2016-2019] (28 p.). (In Ukrainian). Retrieved from https://bitly.su/RfqmEc1

10. Kabinet Ministriv Ukrainy (2016). Vystup Premier-ministra Ukrainy Volodymyra Hroismana pid chas predstavlennia Prohramy diialnosti Kabinetu Ministriv Ukrainy na zasidanni Verkhovnoi Rady Ukrainy [Speech by the Prime Minister of Ukraine Volodymyr Groysman during the presentation of the Program of Activities of the Cabinet of Ministers of Ukraine at the Verkhovna Rada of Ukraine]. (In Ukrainian). Retrieved from https://www.kmu.gov.ua/ua/news/248960727

11. Keins, Dzh. M. (1999). Obshchaia teoryia zaniatosty, protsenta y deneh [The General Theory of Employment, Interest and Money] (262 p.). Moskva: Gelios ARV. (In Russian)

12. Kolot, A. M., \& Herasymenko, O. O. (2019). Social and Labor Development in The Xxi Century: to the Nature of Global Changes, New Opportunities, Limitations and Challenges. Demohrafia ta sotsialna ekonomika, 1, 97-125. (In Ukrainian). Retrieved from https://bitly.su/ hzSYMkkT

13. Korolov, O. A. (2002). Ekonometriia [Econometrics] (660 p.). Kyiv: Yevropeiskyi universytet.

14. Krugman, P. (2013). Vykhod iz krizisa yest! [End This Depression Now!] (320 p.). Moskva: Azbuka. (In Russian)

15. Kulikov, G. T. (2016). Yak rozirvaty porochne kolo nyzkykh zarobitnykh plat [How to Break the Vicious Circle of Low Wages]. (In Russian). Retrieved from https://zn.ua/macrolevel/kak-razorvat-porochnyy-krug-nizkih-zarabotnyh-plat-_.html

16. Libanova, E. M. (Ed.) (2016). Liudskyi rozvytok v Ukraini. Innovatsiini vydy zainiatosti ta perspektyvy yikh rozvytku [Human development in Ukraine. Innovative types of employment and prospects for their development] (328 p.). Kyiv: Instytut demohrafii ta sotsialnykh doslidzhen im. M. V. Ptukhy NAN Ukrainy. (In Ukrainian). Retrieved from https://www.idss.org.ua/monografii/2017_lud_rozvytok.pdf

17. Makkonnell, K. R., Bryu, S. L., \& Stenli, L. (1998). Ekonomiks: printsipy, problemy i politika [Economics: principles, problems and politics] (785 p.). Kyiv: KhaHar. (In Russian)

18. Marshavin, Yu. M. (2018). Modernization of workplaces as the development imperative of employment. Rynok pratsi ta zainiatist naselennia, 2, 5-14. (In Ukrainian). Retrieved from http://nbuv.gov.ua/UJRN/rpzn_2018_2_3

19. Mortensen, D. T. (2010). Wage Dispersion in the Search and Matching Model. American Economic Review: Papers and Proceedings, 100(2), 338-342. https://doi.org/10.1257/aer.100.2.338

20. Natsionalnyi bank Ukrainy (n.d.). Hroshovo-kredytna statystyka. Ohlyady finansovykh korporatsiy [Monetary statistics. Reviews of financial corporations]. (In Ukrainian). Retrieved from https://bank.gov.ua/files/3.1-Monetary_Statistics.xlsx

21. Natsionalnyi instytut stratehichnykh doslidzhen (n.d.). Stvorennia novykh robochykh mists $v$ Ukraini: rezultaty ta perspektyvy [Creating New Jobs in Ukraine: Results and Prospects]. (In Ukrainian). Retrieved from http://old.niss.gov.ua/monitor/october09/15.htm

22. Petrova, I. L. (Ed.) (2016). Rozvytok sotsialno-trudovoi sfery Ukrainy: teoriia, praktyka, perpektyvy [Development of social and labor sphere of Ukraine: theory, practice, prospects] (326 p.). Kyiv: Instytut ekonomiky ta prohnozuvannia NAN Ukrainy. (In Ukrainian). Retrieved from https://bitly.su/vaOry

23. Pissarides, C. A. (2009). The Unemployment Volatility Puzzle: Is Wage Stickiness the Answer? Econometrica, 77(5), 1339-1369. https://doi. org/10.3982/ECTA7562

24. Pyshchulina, O. M., Koval, O. P., \& Kochemyrovska, O. O. (2010). Systemni vady rynku pratsi ta priorytety yoho reformuvannia: analitychna dopovid [Systemic disadvantages of the labor market and its reforming priorities: analytical report] (72 p.). Kyiv: NISD. (In Ukrainian). Retrieved from http://old2.niss.gov.ua/articles/483/

25. Simons, H. (1948). Economic Policy for Free Society (161 p.). Chicago: The University of Chicago Press.

26. Verkhovna Rada Ukrainy (2005). Pro vdoskonalennia derzhavnoho rehuliuvannia u sferi zainiatosti naselennia ta rynku pratsi v Ukraini [On improvement of state regulation in the sphere of employment and the labor market in Ukraine]. (In Ukrainian). Retrieved from http:// zakon3.rada.gov.ua/laws/show/1073/2005

27. Verkhovna Rada Ukrainy (2009). Pro vnesennia zmin do deiakykh zakoniv Ukrainy shchodo zmenshennia vplyvu svitovoi finansovoi kryzy na sferu zainiatosti naselennia [Amending Some Laws of Ukraine to Reduce the Impact of the Global Financial Crisis on Employment]. (In Ukrainian). Retrieved from https://zakon.rada.gov.ua/laws/show/799-17 
28. Verkhovna Rada Ukrainy (2012). Pro zatverdzhennia Prohramy spryiannia zainiatosti naselennia ta stymuliuvannia stvorennia novykh robochykh mists na period do 2017 roku [About Approving the Employment Promotion Program and Stimulation of Creation New Jobs up to 2017] (In Ukrainian). Retrieved from https://zakon.rada.gov.ua/laws/show/1008-2012-\%D0\%BF

29. Verkhovna Rada Ukrainy (2013). Pro zainiatist naselennia [On employment of the population]. (In Ukrainian). Retrieved from http://zakon2.rada.gov.ua/laws/show/5067-17

30. Verkhovna Rada Ukrainy (2015). Pro Stratehiiu staloho rozvytku "Ukraina - 2020” [About Ukraine - 2020 Sustainable Development Strategy] (In Ukrainian). Retrieved from https://zakon.rada.gov.ua/laws/show/5/2015/conv 